\title{
Socioeconomic and family influences on dental treatment needs among Brazilian underprivileged schoolchildren participating in a dental health program
}

\author{
Cristina Martins Lisboa, Janice Simpson de Paula, Glaucia Maria Bovi Ambrosano, Antonio Carlos Pereira, \\ Marcelo de Castro Meneghim, Karine Laura Cortellazzi, Fabiana Lima Vazquez and Fábio Luiz Mialhe*
}

\begin{abstract}
Background: The objective of this study was to compare the socioeconomic and family characteristics of underprivileged schoolchildren with and without curative dental needs participating in a dental health program.

Methods: A random sample of 1411 of 8-to-10 year-old Brazilian schoolchildren was examined and two sample groups were included in the cross-sectional study: 544 presented curative dental needs and the other 867 schoolchildren were without curative dental needs. The schoolchildren were examined for the presence of caries lesions using the DMFT index and their parents were asked to answer questions about socioenvironmental characteristics of their families. Logistic regression models were adjusted estimating the Odds Ratios (OR), their 95\% confidence intervals $(\mathrm{Cl})$, and significance levels.

Results: After adjusting for potential confounders, it was found that families earning more than one Brazilian minimum wage, having fewer than four residents in the house, families living in homes owned by them, and children living with both biological parents were protective factors for the presence of dental caries, and consequently, curative dental needs.
\end{abstract}

Conclusions: Socioeconomic status and family structure influences the curative dental needs of children from underprivileged communities. In this sense, dental health programs should plan and implement strategic efforts to reduce inequities in oral health status and access to oral health services of vulnerable schoolchildren and their families.

Keywords: Socioenvironmental aspects, Oral health, Access health services

\section{Background}

Oral health is intrinsically linked to general health and quality of life. The impact of oral diseases on individuals is reflected in their days lost at school and work, difficulty with eating, reduced self-esteem, poor quality of life, among other consequences [1,2].

According to a national survey conducted in Brazil in 2010, 18.1\% of children aged 12 years had never been to the dentist, and of these, $60.8 \%$ reported curative dental treatment needs [3]. This situation indicates that there

\footnotetext{
* Correspondence: mialhe@fop.unicamp.br

Department of Community Dentistry, Piracicaba Dental School, University of Campinas-UNICAMP, P.O. BOX 52, 13414-903 Piracicaba, SP, Brazil
}

are inequalities in oral health and difficulties in access to dental care experienced by this population.

The benefits of access to dental treatment have been discussed in several articles, such as the study of Alkarimi et al. [4], who reported that the treatment of caries in schoolchildren improved their oral health conditions and satisfaction with their teeth, smile and appetite, which in turn, have a strong influence on their overall health. In addition, other studies have shown the impact of orthodontic treatment, periodontal treatment and early childhood caries treatment on the subjective perceptions of quality of life between schoolchildren and their parents [5-11]. 
Dental schools play an important role in promoting access to dental services for schoolchildren [12-18]. In Brazil, the Piracicaba Dental School has developed a project entitled "Program Always Smiling" (PAS) in partnership with public and private institutions, with the main objective of offering dental care to approximately 3,000 underprivileged children between 6 to 10 years of age from public schools in Piracicaba, São Paulo, Brazil each year. The dental care model proposed in the project comprises preventive and curative interventions with the aim of promoting the oral health of children and their families [19].

Although the influence of social determinants on oral health has been recognized in the literature [20,21], little is known about the differences in socioeconomic and family characteristics between schoolchildren with and without curative dental needs, belonging to povertyincome groups. Thus, the objective of this study was to investigate the socioeconomic and family characteristics of schoolchildren with and without curative dental needs, from poor families participating in a dental health program.

\section{Methods}

\section{Ethical aspects}

Before this study was conducted, the project was approved by the Research Ethics Committee (No. 111/2010) of the Piracicaba Dental School, University of Campinas. The inclusion of children and parents to participate in this study depended on obtaining written permission from the children's parents/guardians, for this purpose.

\section{Sample}

The city of Piracicaba has 55 primary schools with a total of 10,155 schoolchildren in the age group 8-10 years, enrolled in 2011. From the social exclusion index (SEI), an index elaborated by local government on the basis of social indicators of the city neighborhoods, it was possible to identify the schools belonging to the areas with high vulnerability, i.e., those with the worst SEI [22]. Of these, 9 public schools were randomly selected by the cluster sampling method. To calculate the sample size of the study, a power of $90 \%$ was considered, with an odds ratio of 1.5 and percentage response from the unexposed group of $35 \%$, resulting in the selection 1411 children aged 8-10 years from Piracicaba, São Paulo, Brazil. Among them, 544 presented curative dental needs and were treated in the PAS and the other 867 schoolchildren were without curative dental needs.

The exclusion criteria were schoolchildren who were outside the stipulated age of 8 to 10 years; those with debilitated health; whose parents did not grant permission for participation in the study; or who did not responded satisfactorily to the questionnaire.

\section{Examination methodology}

The data concerning the clinical characteristics of the schoolchildren attended by the PAS were obtained by dentists working in the municipal health system in partnership with the program. The dentists examined all children using a dental probe and mirror, under natural light in outdoor setting. Dental caries were registered using the DMFt and dmft indexes according to the World Health Organization recommendations [23]. Before data collection, practical and theoretical activities were performed in calibration exercises. Intra and inter-examiner reliability was assessed by Kappa statistics and a percentage agreement (higher than 0.85 ) was considered good.

\section{Questionnaire}

Information about the socioenvironmental characteristics of the schoolchildren's families were collected by means of a questionnaire sent to their parents. This instrument addressed issues related to socioeconomic characteristics (family income, parents' educational level, home ownership, government assistance, parents' occupation), and family environment (number of residents in the house, children living with both biological parents, schoolchildren's caregivers outside of school hours). Data on the children's gender were also collected. The questionnaire used was adapted from Paula et al. [2].

\section{Data analysis}

Bivariate analyses using the Chi-square test $\left(x^{2}\right)$ were performed to test the influence of independent variables on dependent variables. The independent variables were: monthly family income, based on the number of minimum wages which the family receives $(\leq 1$ and $>1$ minimum wages), considering the Brazilian minimum wage $(\mathrm{BMW})$ at time of data collection of approximately US\$ 290 per month; parents' educational level (up to 8 and more years of schooling); number of residents in the children's house (up to 4 or more); home ownership (yes/no); family government assistance (yes/no), children living with both biological parents (yes/no), father's occupation (unemployed/employee; mother's occupation (housewife, employee); schoolchildren's caregivers outside of school hours (parents/others), data that were dichotomized according other studies [24-26] and/or by the median. The dependent variable treatment need was dichotomized into 'with curative dental needs' and 'without curative dental needs'. After this multiple logistic regression analyses using the stepwise procedure were performed in order to identify the risk indicators for treatment need. Only the independent variables with $\mathrm{p}$ value less than 0.20 were tested in the regression analysis in order to eliminate those that would make little contribution to the model, and those with $\mathrm{p} \leq 0.05$ remained in model after the adjustments. The logistic regression models were adjusted estimating 
the Odds Ratios (OR), their 95\% confidence intervals (CI), and significance levels. All statistical tests were performed using the SAS software program (SAS institute Inc 2001, version 9.2, Cary, North-Carolina/USA) [27] at 5\% significance level.

\section{Results}

The sample was composed of a similar number of male $(49 \%)$ and female (51\%) subjects. As regards socioeconomic variables, $66.9 \%$ of families had an income $\leq 1$ Brazilian minimum wages and most fathers $(62.3 \%)$ and mothers $(60.5 \%)$ had attended school for fewer than 8 years. With respect to family environment, $63.7 \%$ of children lived with both biological parents and 44.7\% stayed with caregivers other than their parents outside school hours (Table 1).

With reference to caries prevalence in the treated schoolchildren, the $\mathrm{dmft}$ was $2.01 \quad(\mathrm{SD}=2.06)$, DMFT was $0.44(\mathrm{SD}=1.22)$, and $132(24.2 \%)$ of the schoolchildren had more than one affected tooth ( $>1$ carious teeth).

Table 2 shows the association of independent variables with treatment need according to the Chi-square test. High monthly family income, father's and mother's high educational level, lower number of residents in the house, family living in home ownership properties, family without government assistance, children living with both biological parents and father and/or mother being the children's caregivers outside school hours was associated with reduced dental treatment need $(\mathrm{p} \leq 0.05)$.

All the variables with $\mathrm{p}<0.20$ were selected for the multiple logistic regression analysis. Among them, families earning more than one Brazilian minimum wage, having fewer than four residents in the house, families living in home-ownership properties and children living with both biological parents were protective factors for the presence of dental caries, and consequently, curative dental needs (Table 3). Therefore, children from families earning more than one minimum wage, residing with fewer people in the house, who live in their own home and with their biological parents showed less chance of having curative dental needs.

\section{Discussion}

The results presented in this study revealed that there are social inequalities in the oral health of schoolchildren, even within a population with low socioeconomic status. Several researchers have emphasized the family environment and its socioeconomic conditions as mediators of health and disease in schoolchildren [28-32]. In the final logistic regression model, it was observed that children living in homes with a monthly family income of more than one Brazilian minimum wage, had less chance of presenting curative dental needs than their counterparts, a finding similar to that shown in the study of Paredes
Table 1 Characteristics of schoolchildren participating in the Program "Always Smiling"

\begin{tabular}{|c|c|c|}
\hline Variable & $\mathbf{n}$ & $\%$ \\
\hline \multicolumn{3}{|l|}{ Gender } \\
\hline Male & 701 & 49.0 \\
\hline Female & 710 & 51.0 \\
\hline \multicolumn{3}{|l|}{ Monthly family income } \\
\hline$\leq 1$ minimum wage* & 385 & 66.9 \\
\hline$>1$ minimum wage & 942 & 33.1 \\
\hline \multicolumn{3}{|l|}{ Father's education } \\
\hline$\leq 8$ years & 639 & 62.3 \\
\hline$>8$ years & 387 & 37.7 \\
\hline \multicolumn{3}{|l|}{ Mother's education } \\
\hline$\leq 8$ years & 818 & 60.5 \\
\hline$>8$ years & 533 & 39.5 \\
\hline
\end{tabular}

Number of residents in the house

$\begin{array}{lll}>4 \text { persons } & 698 & 50.7 \\ \leq 4 \text { persons } & 679 & 49.3\end{array}$

Home ownership

$\begin{array}{lll}\text { No } & 556 & 40.2 \\ \text { Yes } & 827 & 59.8\end{array}$

Government assistance

$\begin{array}{lcc}\text { Yes } & 393 & 28.2 \\ \text { No } & 1000 & 71.8\end{array}$

Children living with both biological parents

$\begin{array}{lll}\text { No } & 511 & 36.3 \\ \text { Yes } & 859 & 63.7\end{array}$

Father's ocupation

Unemployed 139

$\begin{array}{lll}\text { Employed } & 907 & 96.7\end{array}$

Mother's ocupation

$\begin{array}{lll}\text { Housewife } & 587 & 45.0\end{array}$

Employee $\quad 718 \quad 55.0$

Schoolchildren's caregivers outside of school hours

\begin{tabular}{lll} 
Others & 611 & 44.7 \\
Father and/or Mother & 755 & 55.3 \\
\hline
\end{tabular}

Piracicaba, Brazil, 2011.

*Minimum wage at the time of data collection, approximately US\$290.00.

et al. [33]. Thus, even in underprivileged families, we found a deprivation gradient for dental caries experience and curative dental needs. It is known that underprivileged families have less access to broader and better health information, fewer resources to buy and replace oral hygiene aids, and fewer favorable conditions to make healthier choices, including dietary choices and access to dental care [29-34]. In addition, individuals in poor socioeconomic situations suffer from psychological and social problems 
Table 2 Bivariate analysis for association between treatment need and socioenvironmental profile

\begin{tabular}{|c|c|c|c|c|c|c|c|c|c|}
\hline \multirow[b]{2}{*}{ Variable } & \multirow[b]{2}{*}{ Categories } & \multirow[b]{2}{*}{ Total } & \multicolumn{2}{|c|}{$\begin{array}{l}\text { With curative } \\
\text { dental need }\end{array}$} & \multicolumn{2}{|c|}{$\begin{array}{l}\text { Without curative } \\
\text { dental need }\end{array}$} & \multirow[b]{2}{*}{ OR } & \multirow[b]{2}{*}{$\mathrm{Cl} 95 \%$} & \multirow[b]{2}{*}{$\mathrm{p}$} \\
\hline & & & $\mathrm{N}$ & $\%$ & $n$ & $\%$ & & & \\
\hline \multirow[t]{2}{*}{ Gender } & Male & 700 & 270 & 38.6 & 430 & 61.4 & Ref & & \\
\hline & Female & 711 & 274 & 38.5 & 437 & 61.5 & 1.00 & $0.8059-1.2373$ & 0.9895 \\
\hline \multirow[t]{2}{*}{ Monthly family income } & $\leq 1$ minimum wage ${ }^{*}$ & 385 & 179 & 46.5 & 206 & 53.3 & Ref & & \\
\hline & $>1$ minimum wage & 942 & 334 & 35.5 & 608 & 64.5 & 0.63 & $0.4970-0.8042$ & 0.0002 \\
\hline \multirow[t]{2}{*}{ Father's education } & $\leq 8$ years & 639 & 255 & 40.0 & 384 & 60.0 & Ref & & \\
\hline & $>8$ years & 387 & 124 & 32.0 & 263 & 68.0 & 0.71 & $0.5443-0.9262$ & 0.0116 \\
\hline \multirow[t]{2}{*}{ Mother's education } & $\leq 8$ years & 818 & 337 & 41.0 & 481 & 59.0 & Ref & & \\
\hline & $>8$ years & 533 & 186 & 35.0 & 347 & 65.0 & 0.76 & $0.610-0.959$ & 0.0203 \\
\hline \multirow[t]{2}{*}{ Number of residents in the house } & $>4$ persons & 698 & 287 & 41.0 & 411 & 59.0 & Ref & & \\
\hline & $\leq 4$ persons & 679 & 244 & 36.0 & 435 & 64.0 & 0.80 & $0.646-0.998$ & 0.0484 \\
\hline \multirow[t]{2}{*}{ Home ownership } & No & 556 & 236 & 42.5 & 320 & 57.5 & Ref & & \\
\hline & Yes & 827 & 298 & 36.0 & 529 & 64.0 & 0.76 & $0.613-0.952$ & 0.0164 \\
\hline \multirow[t]{2}{*}{ Government assistance } & Yes & 393 & 180 & 45.9 & 213 & 54.1 & Ref & & \\
\hline & No & 1000 & 358 & 35.8 & 642 & 64.2 & 0.66 & $0.521-0.836$ & 0.0006 \\
\hline \multirow[t]{2}{*}{ Children living with both biological parents } & No & 511 & 225 & 44.0 & 286 & 56.0 & Ref & & \\
\hline & Yes & 859 & 302 & 35.1 & 557 & 64.9 & 0.69 & $0.551-0.862$ & 0.0011 \\
\hline \multirow[t]{2}{*}{ Father's ocupation } & Unemployed & 139 & 61 & 43.8 & 78 & 56.2 & Ref & & \\
\hline & Employed & 907 & 323 & 35.6 & 584 & 64.4 & 0.71 & $0.493-1.015$ & 0.0604 \\
\hline \multirow[t]{2}{*}{ Mother's ocupation } & Housewife & 587 & 208 & 35.5 & 379 & 64.5 & Ref & & \\
\hline & employee & 718 & 290 & 40.4 & 428 & 59.6 & 1.23 & $0.985-1.547$ & 0.0669 \\
\hline \multirow[t]{2}{*}{ Schoolchildren's caregivers outside of school hours } & Others & 611 & 258 & 42.2 & 353 & 57.8 & Ref & & \\
\hline & Father and/or Mother & 755 & 264 & 35.0 & 491 & 65.0 & 0.74 & $0.591-0.916$ & 0.0061 \\
\hline
\end{tabular}

Piracicaba, Brazil, 2011.

*Minimum wage at the time of data collection, approximately US\$290,00.

$\mathrm{OR}=$ Odds Ratio.

$\mathrm{Cl}=$ Confidence Intervals

Reference levels of dependent variable: treatment need.

Table 3 Multiple logistic regression for association between treatment need and socioenvironmental profile

\begin{tabular}{|c|c|c|c|c|c|c|c|c|c|}
\hline & & \multirow[b]{2}{*}{ Total } & \multicolumn{2}{|c|}{$\begin{array}{l}\text { With curative } \\
\text { dental need }\end{array}$} & \multicolumn{2}{|c|}{$\begin{array}{l}\text { Without curative } \\
\text { dental need }\end{array}$} & \multirow[b]{2}{*}{ OR } & \multirow[b]{2}{*}{$\mathrm{Cl} 95 \%$} & \multirow[b]{2}{*}{$\mathrm{p}$} \\
\hline & & & $\mathrm{n}$ & $\%$ & $\mathbf{n}$ & $\%$ & & & \\
\hline \multirow[t]{2}{*}{ Monthly family income } & $\leq 1$ minimum wage* & 385 & 179 & 46.5 & 206 & 53.3 & Ref & & \\
\hline & $>1$ minimum wage & 942 & 334 & 35.5 & 608 & 64.5 & 0.73 & $0.567-0.944$ & 0.0162 \\
\hline \multirow[t]{2}{*}{ Number of residents in the house } & $>4$ persons & 698 & 287 & 41.0 & 411 & 59.0 & Ref & & \\
\hline & $\leq 4$ persons & 679 & 244 & 36.0 & 435 & 64.0 & 0.77 & $0.615-0.973$ & 0.0281 \\
\hline \multirow[t]{2}{*}{ Home ownership } & No & 556 & 236 & 42.5 & 320 & 57.5 & Ref & & \\
\hline & Yes & 827 & 298 & 36.0 & 529 & 64.0 & 0.78 & $0.623-0.994$ & 0.0440 \\
\hline \multirow[t]{2}{*}{ Children living with both biological parents } & No & 511 & 225 & 44.0 & 286 & 56.0 & Ref & & \\
\hline & Yes & 859 & 302 & 35.1 & 557 & 64.9 & 0.72 & $0.570-0.923$ & 0.0091 \\
\hline
\end{tabular}

Piracicaba, Brazil, 2011

*Minimum wage at the time of data collection, approximately US\$290,00.

OR $=$ Odds Ratio

$\mathrm{Cl}=$ Confidence Intervals.

Reference levels of dependent variable: treatment need. 
because of living in poverty, influencing the way parents care for their children $[35,36]$.

Children participating in PAS, who were living with fewer than 4 residents in the home, had less chance of having curative dental needs than those who lived with more than 4 residents in the home. Studies have shown that household overcrowding had an inverse relationship with healthy habits of nutrition and hygiene, oral healthrelated quality of life, and were predictors of traumatic dental injuries in children and adolescents [2,37-39]. Thus, overcrowding may have both direct and indirect effects on the general and oral health of the members of families, and poorer schoolchildren living in homes with fewer individuals was a protective factor for curative dental needs.

Home ownership, an environmental living condition, was another protective factor associated with fewer curative dental needs in schoolchildren, differing from the findings of Pereira et al. [40], which did not observe any associations with the DMFT index in 12 year-olds in the same city as the one of this study. However, their study sample was composed of children from public and private schools in Piracicaba, São Paulo, Brazil and the majority of their families had a monthly family income of over 2 Brazilian minimum wages. Studies have shown that home ownership may improve the psychological well-being of homeowners and support better parenting practices, which may lead to better child outcomes even in disadvantaged families [41-43]. Therefore, it is important that this variable be taken into account by health managers when planning their actions, in order to reduce inequities in oral health of this population, and increase its access to oral health services.

Family structures are changing globally and in Brazil, with an increasing number of non-nuclear and nonbiological parents [44], studies have shown that family structure can have an impact on the oral health status, oral health-related quality of life, and self-perceived oral health of children and adolescents [2,29,45,46]. It was observed that underprivileged children living with both biological parents was a protective factor, as they presented fewer restorative dental treatment needs than those from non-nuclear families. The literature provides evidences that nuclear families were more likely to have a supportive economic and psychological environment for performing better health behaviors than the environment provided by single or separated parents. The latter are generally more stressed to earn enough income to sustain their children, resulting in negligent attitudes towards monitoring oral health and using dental services for both themselves and their children [29,34,45-47].

In addition to the direct impact of social determinants of health on children's oral health, behavioral, psychological and social factors could also generate inequities of access to dental services, as poorer children were less likely to use these services [31,48-51]. As observed in the present study, most of the schoolchildren needing dental curative care were those living with families in worse economic and home environments, which highlight the importance of community dental health programs such as PAS to create mechanisms to improve access to and the use of dental services by those who most need them, thereby creating equity in access to health and not an "inverse care law" demand $[48,52,53]$.

The literature presents several suggestions to increase dental attendance for children. Tellen et al. [50] point out that to encourage access to dental care for schoolchildren, it is necessary for mothers to incorporate the value of preventive and curative dental care into their children's upbringing, especially in vulnerable populations. However, socioeconomic and psychological aspects of parents such as scheduling caregivers, transportation difficulties, fear of the dentist, provider availability, past satisfaction with dental care received, oral health beliefs, among other factors, could be a barrier that restrains/prevents the capacity of motivation from being transformed into action, impeding the access of low-income caregivers to oral health services for their children, and leading to them having a higher level of accumulated treatment needs $[48,50,51]$.

The organization of the PAS project, unlike many dental programs, is based on the formation of a strategic network of institutional, financial and personnel support of key partners that enables continuous and comprehensive care for school children. The PAS project used its own transport donated by the Municipal Department of Education, to take schoolchildren to school and take on-site dental service to them, thereby facilitating access to dental care. All children are accompanied by educational monitors from participating schools. The goal of this strategy is to overcome the barriers imposed by the geographical location of services and indirect costs involved in transporting children to their dental treatment [54-56]. Moreover, the organization of PAS services during school hours allows greater accessibility to children's dental care, since there is no need for parents to lose working hours to take their children for dental treatment [12]. In addition, this system facilitates the decision making of parents to take care of oral health needs of their children, instead of relying on the parents' individual motivation to seek care for them. It is known that even in reimbursement systems there is no significant increase in their use by these groups [57].

Another important aspect of the PAS project is the participation of school teachers and principals in raising the awareness of parents about the importance of children's participation in the program. According to Telleen et al. [50] mothers who had satisfactory communication with the dentist, who believed that dentist's visits were for 
the purpose of keeping the child's teeth healthy and believed in the importance of taking the child to the dentist regularly were more likely to return to the dental office regularly. Furthermore, dental screening at schools, performed by dentists participating in the program, helps with the detection of normative dental treatment needs that are often not detected by the guardians [14]. Similar programs have been developed in the UK and India demonstrating that the active search for cases of diseases in schools encourages access to dental care and awareness of both parents and children of the need for this, especially among low-income groups $[58,59]$. Therefore, health programs such as PAS, based on healthy alliances, and targeting resources to areas of greatest social exclusion are an essential requirement for tackling the oral health inequalities of children [60].

Despite the fact that dental services generally do not deal with the social determinants of health that affect oral diseases, it is known they have important impact on health inequalities when they improve accessibility and respond appropriately to the healthcare needs of different social groups [20]. Evidence has shown that the availability of a regular source of dental care was a strong predictor of dental visits in the past 12 months, among persons in a vulnerable population. Thus, improving access to oral health services could allow standardization of the risk profile of children from different sociodemographic backgrounds and impact significantly on the percentage of children requiring urgent dental treatment, and on the number of decayed teeth in children at low-income schools $[49,54,61]$. Therefore, it would be better for dental professionals to know the impact of socioenviromental conditions and family structure on the oral health of individuals, in order to plan intersectorial actions, as in the case of PAS, which positively impact the health of populations in a sustainable manner, especially those who are most vulnerable [62-65].

In spite of the significant results observed and discussed in this study, some limitations should be considered. It is a cross-sectional study, in which the causal relationship cannot be adequately assessed. Therefore, longitudinal follow-up is required for further insights into the impact of PAS on the reduction of inequalities in oral health of underprivileged schoolchildren.

\section{Conclusion}

In conclusion, it was observed that socioeconomic status and family structure influences the curative dental needs of children from underprivileged communities. In this sense, dental care services based on the principles of the PAS project should be relevant to reduce inequities in oral health status and access to oral health services, positively impacting on the quality of life of vulnerable schoolchildren.
Competing interests

The authors declare that they have no competing interests.

\section{Authors' contributions}

$C M L$ and JSP participated in the conception and design of the study, data interpretation, data acquisition, and drafting the manuscript. GMBA and KLC participated in data analyses. ACP and MCM contributed to critical revision of manuscript. FLV contributed to the data collection. FLM participated in the conception and design of the study and critical revision of manuscript. All authors read and approved the final manuscript.

\section{Acknowledgements}

This study was supported by FAPESP (process no 2011/17669-5), São Paulo, Brazil.

Received: 22 July 2013 Accepted: 16 October 2013

Published: 19 October 2013

\section{References}

1. Sheiham A, Alexander D, Cohen L, Marinho V, Moysés S, Petersen PE, Spencer J, Watt RG, Weyant R: Global oral health inequalities: task group-implementation and delivery of oral health strategies. Adv Dent Res 2011, 23:259-267.

2. Paula JS, Leite ICG, Almeida AB, Ambrosano GMB, Pereira AC, Mialhe FL: The influence of oral health conditions, socioeconomic status and home environment factors on schoolchildren's self-perception of quality of life. Health Qual Life Outcomes 2012, 10:6.

3. Ministério da Saúde: Projeto SB Brasil 2010: condições de saúde bucal da população brasileira: resultados principais. Brasil: Brasília: Departamento de Atenção Básica, Secretaria de Atenção à Saúde, Ministério da Saúde; 2010. in Portuguese.

4. Alkarimi HA, Watt RG, Pikhart H, Jawadi AH, Sheiham A, Tsakos G: Impact of treating dental caries on schoolchildren's anthropometric, dental, satisfaction and appetite outcomes: a randomized controlled trial. BMC Public Health 2012, 12:706.

5. Agou S, Locker D, Streiner DL, Tompson B: Impact of self-esteem on the oral-health-related quality of life of children with malocclusion. Am J OrthodDentofacialOrthop 2008, 134(4):484-489.

6. Azuma S, Kohzuki M, Saeki S, Tajima M, Igarashi K, Sugawara J: Beneficial effects of orthodontic treatment on quality of life in patients with malocclusion. Tihoku J Exp Med 2008, 214:39-50.

7. Feu D, De Oliveira BH, De Oliveira Almeida MA, Kiyak HA, Miguel JA: Oral health-related quality of life and orthodontic treatment seeking. Am J OrthodDentofacialOrthop 2010, 138(2):152-159.

8. Taylor KR, Kiyak A, Huang GJ, Greenlee GM, Jolley CJ, King GJ: Effects of malocclusion and its treatment on the quality of life of adolescents. Am J Orthod Dentofacial Orthop 2009, 136(3):382-392.

9. Zhang M, McGrath C, Hägg U: Patients expectations and experiences of fixed orthodontic appliance therapy. Angle Orthod 2007, 77(2):318-322.

10. Ohrn K, Jönsson B: A comparison of two questionnaires measuring oral health-related quality of life before and after dental hygiene treatment in patients with periodontal disease. Int J Dent Hyg 2012, 10(1):9-14

11. Cunnion DT, et al: Pediatric oral health-related quality of life improvement after treatment of early childhood caries: a prospective multisite study. J Dent Child 2010, 77:4-11.

12. Simoyan $\mathrm{O}$, Badner $\mathrm{V}$ : Implementing a school-based dental health program: the Montefiore model. J Sch Health 2002, 72(6):262-263.

13. Diamond R, Litwak E, Marshall S, Diamond A: Implementing a community-based oral health care program: lessons learned. J Public Health Dent 2003, 63(4):240-243.

14. Locker D, Frosina C, Murray H, Wiebe D, Wiebe P: Identifying children with dental care needs: evaluation of a targeted school-based dental screening program. J Public Health Dent 2004, 64(2):63-70.

15. Albert DA, McManus JM, Mitchell DA: Models for delivering school-based dental care. J Sch Health 2005, 75(5):157-161.

16. Devlin D, Henshaw M: Improving access to preventive dental services through a school-based dental sealant program. J Dent Hyg 2011, 85(3):211-219 
17. Simmer-Beck M, Gadbury-Amyot CC, Ferris H, Voelker MA, Keselyak NT, Eplee H, Parkinson J, Marse B, Galemore C: Extending oral health care services to underserved children through a school-based collaboration: part 1: a descriptive overview. J Dent Hyg 2011, 85(3):181-192

18. Fine JI, Isman RE, Grant CB: A comprehensive school-based/linked dental program: an essential piece of the California access to care puzzle. J Calif Dent Assoc 2012, 40(3):229-237.

19. Taglietta, et al: Impact of one health promotion program on dental caries prevalence reduction in pre-school children of Piracicaba-SP. RFO 2011, 16:13-17.

20. Watt RG: Social determinants of oral health inequalities: implications for action. Community Dent Oral Epidemiol 2012, 40:44-48.

21. Petersen PE, Kwan S: Equity, social determinants and public health programmes-the case of oral health. Community Dent Oral Epidemio 2011, 39:481-487.

22. IPPLAP: Institute for research and planning of Piracicaba. 2011. (in Portuguese) Available at <http://ipplap.com.br/site/piracicaba-em-dados> Accessed June 2013.

23. World Health Organization: Oral health surveys: basic methods. 4th edition. Geneva: World Health Organization; 1997.

24. De Paula JS, Leite IC, De Almeida AB, Ambrosano GM, Mialhe FL: The impact of socioenvironmental characteristics on domains of oral health-related quality of life in Brazilian schoolchildren. BMC Oral Health 2013, 13:10.

25. Oliveira LB, Sheiham A, Bonecker M: Exploring the association of denta caries with social factors and nutritional status in Brazilian preschool children. Eur J Oral Sci 2008, 116:37-43.

26. Alves Luna AC, Rodrigues MJ, Menezes VA, Marques KMG, Santos FA: Caries prevalence and socioeconomic factors in children with sickle cell anemia. Braz Oral Res 2012, 26(1):43-49.

27. SAS Institute Inc: SAS/STAT guide for personal computers. 92nd edition. North-Carolina/USA: Cary; 2001

28. Christensen P: The health-promoting family: a conceptual framework for future research. Soc Sci Med 2004, 59:377-387.

29. Fisher-Owen SA, Gansky SA, Platt $\amalg$, Weintraub JA, Soobader MJ, Bramlett MD, Newacheck PW: Influences on children's oral health: a conceptual model. Pediatrics 2007, 120:510-520

30. Bonanato K, Pordeus IA, Moura-Leite FR, Ramos-Jorge ML, Vale MP Paiva SM: Oral disease and social class in a random sample of five-year-old preschool children in a Brazilian city. Oral Health Prev Dent 2010, 8(2):125-132.

31. Da Rosa P, Nicolau B, Brodeur JM, Benigeri M, Bedos C, Rousseau MC: Associations between school deprivation indices and oral health status. Community Dent Oral Epidemiol 2011, 39:213-220.

32. Castilho ARF, Mialhe FL, Barbosa TS, Puppin-Rontani RM: Influence of family environment on children's oral health: a systematic review. J Pediatr 2013, 89(2):116-123.

33. Paredes SO, Almeida DB, Fernandes JMFA, Forte MDS, Sampaio FC: Behavioral and social factors related to dental caries in 3 to 13 year-old children from João Pessoa, Paraíba Brazil. Rev odonto ciênc 2009, 24(3):231-235

34. Nicolau B, Marcenes W, Bartley M, Sheiham A: A life course approach to assessing causes of dental caries experience: the relationship between biological, behavioural, socio-economic anda psychological conditions and caries in adolescents. Caries res 2003, 37:319-326.

35. Blackburn C: Poverty and health: working with families. Buckinghan: Open University Press; 1991.

36. Shaw M, Dorling D, Smith GD: Poverty, social exclusion, and minorities. In Social determinants of health. 2nd edition. Edited by Marmot M, Wilkinson R. USA: Oxford University Press; 2005.

37. Antunes JLF, Frazão P, Narvai PC, Bispo CM, Pegoretti T: Spatial analysis to identify differentials in dental needs by area-based measures. Community Dent Oral Epidemiol 2002, 30:133-142.

38. Marcenes W, Murray S: Changes in prevalence and treatment need for traumatic dental injuries among 14-year-old children in Newham, London: a deprived area. Community Dent Health 2002, 19(2):104-108.

39. Wellappuli NA, Amarasena NB: Influence of family structure on dental caries experience of preschool children in Sri Lanka. Caries Res 2012, 46:208-212.
40. Pereira SM, Tagliaferro EPS, Ambrosano GMB, Cortellazzi KL, Meneghim MC, Pereira AC: Dental caries in 12-year-old Schoolchildren and its relationship with socioeconomic and behavioural variables. Oral Health Prev Dent 2007, 5:299-306.

41. Dietz RD, Haurin DR: The social and private micro-level consequences of homeownership. J Urban Economics 2003, 54:401-450.

42. Cairney J: Housing tenure and psycholo-gical well-being during adolescence. Environ Behav 2005, 37:552-564.

43. Grinstein-Weiss M, Williams Shanks TR, Manturuk KR: Homeownership and parenting practices: evidence from the community advantage panel. Child Youth Serv Rev 2010, 32:774-782

44. IBGE: Pesquisa Nacional por amostra de Domicílios (in Portuguese). The Brazilian Institute of Geography and Statistics. Available at <http://www. ibge.gov.br/home/estatistica/populacao/trabalhoerendimento/pnad2009/ default.shtm> Accessed June 2013.

45. McGrath C, Yeung CY, Bedi R: Are single mothers in Britain failing to monitor their oral health? Postgrad Med J 2002, 78(918):229-232.

46. Ostberg AL, Lindblad U, Halling A: Self-perceived oral health in adolescents associated with family characteristics and parental employment status. Community Dent Health 2003, 20(3):159-164.

47. Mattila ML, Rautava P, Sillanpää M, Paunio P: Caries in five-year-old children and associations with family-related factors. J Dent Res 2000, 79(3):875-881.

48. Milgrom P, Mancl L, King B, Weinstein P, Wells N, Jeffcott E: An explanatory model of the dental care utilization of low-income children. Med Care 1998, 36(4):554-566

49. Davidson PL, Cunningham WE, Nakazono TT, Andersen RM: Evaluating the effect of usual source of dental care on access to dental services: comparisons among diverse populations. Med Care Res Rev 1999, 56(1):74-93.

50. Telleen S, Rhee Kim YO, Chavez N, Barrett RE, Hall W, Gajendra S: Access to oral health services for urban low-income Latino children: social ecological influences. J Public Health Dent 2012, 72(1):8-18

51. Sheiham A, Watt RG: The common risk factor approach: a rational basis for promoting oral health. Community Dent Oral Epidemiol 2000, 28:399-406

52. Hart JT: The inverse care law. Lancet 1971, 297:405-142.

53. Petersen PE: The World Oral Health Report 2003: continuous improvement of oral health in the 21st century-the approach of the WHO Global Oral Health Programme. Community Dent Oral Epidemiol 2003, 31:3-23.

54. Maserejian NN, Tavares MA, Hayes C, Soncini JA, Trachtenberg FL: Prospective study of 5-year caries increment among children receiving comprehensive dental care in the New England children's amalgam trial. Community Dent Oral Epidemiol 2009, 37(1):9-18.

55. Curtis B, Evans RW, Sbaraini A, Schwarz E: Geographic location and indirect costs as a barrier to dental treatment: a patient perspective. Aust Dent J 2007, 52(4):271-275.

56. Tickle M, Moulding G, Milsom K, Blinkhorn A: Socioeconomic and geographical influences on primary dental care preferences in a population of young children. Br Dent J 2000, 188(10):559-562.

57. Azogui-Lévy S, Lombrail P, Riordan PJ, Brodin M, Baillon-Javon E, Pirlet MC, Boy-Lefèvre ML: Evaluation of a dental care program for school beginners in a Paris suburb. Community Dent Oral Epidemiol 2003, 31(4):285-291.

58. Donaldson M, Kinirons M: The effectiveness of the school dental screening programme in stimulating dental attendance for children in need of treatment in Northern Ireland. Community Dent Oral Epidemiol 2001, 29:143-149.

59. Hebbal M, Nagarajappa R: Does school-based dental screening for children increase follow-up treatment at dental school clinics? J Dent Educ 2005, 69(3):382-386.

60. Watt $R$, Sheiham A: Inequalities in oral health: a review of the evidence and recommendations for action. British Dent J 1999, 187:6-12.

61. Muirhead VE, Lawrence HP: Exploring school oral health outcomes and neighbourhood factors in schools participating in Ontario's "Healthy Schools" recognition program. Can J Public Health 2011, 102(1):30-34.

62. Victorino CC, Gauthier AH: The social determinants of child health: variations across health outcomes-a population-based cross-sectional analysis. BMC Pediatr 2009, 9:53 
63. Locker D, Jokovic A, Stephens M, Kenny D, Tompson B, Guyatt G: Family impact of child oral and oro-facial conditions. Community Dent Oral Epidemiol 2002, 30:438-448.

64. McNeill T: Family as a social determinant of health. Healthc Q 2010, 14:60-67.

65. Mattheus DJ: Vulnerability related to oral health in early childhood: a concept analysis. J Adv Nurs 2010, 66(9):2116-2125.

doi:10.1186/1472-6831-13-56

Cite this article as: Lisboa et al: Socioeconomic and family influences on dental treatment needs among Brazilian underprivileged schoolchildren participating in a dental health program. BMC Oral Health 2013 13:56.

\section{Submit your next manuscript to BioMed Central and take full advantage of:}

- Convenient online submission

- Thorough peer review

- No space constraints or color figure charges

- Immediate publication on acceptance

- Inclusion in PubMed, CAS, Scopus and Google Scholar

- Research which is freely available for redistribution 